\section{Quality evaluation of brine shrimp Artemia cysts produced in Asian salt ponds}

Jan Vos', Philippe Léger², Paul Vanhaecke² \& Patrick Sorgeloos²

'Laboratory. for Biochemistry. University of Antwerp RUCA, Slachthuislaan 68, B-2000 Antwerp, Belgium 2 Artemia Reference Center, Laboratory' for Mariculture, State University' of Ghent, J. Plateaustraat 22.
$B-9000$ Ghent, Belgium

Keywords: Artemia, inoculation, salt ponds, cyst quality

\section{Abstract}

Artemia cysts produced in inoculated salt ponds in the Philippines, Thailand and India, were analyzed in comparison with the parental strains used for the inoculations. Cyst hatching efficiency, hatching rate and color changed significantly after inoculation, whereas the cyst's diameters, nauplius survival and nauplius growth remained fairly constant. The nutritional value of the Artemia nauplii was.determined in a standard culture test with Mysidopsis bahia juveniles as test animals. Production results were compared with the fatty acid profiles of the Artemia nauplii. Low levels of the essential fatty acid 20:5 33 in one of the produced cys batches were probably caused by inadequate food conditions in the pond and resulted in poorer growth of the Mysidopsis juveniles. Based on the results of this study a distinction is made between essential and non-essential strain selection-criteria for Artemia inoculations and transplantations.

\section{Introduction}

Brine shrimp Artemia inoculations, i.e. manmanaged introductions of Artemia in seasonal sa ponds (Persoone \& Sorgeloos, 1980) appear to have large potential in the tropical belt in view of the ever increasing demands for live food in local aquaculture hatcheries and nurseries (Sorgeloos, in press). Some countries such as Thailand are very successful in applying this technique and produce Artemia cysts in areas which previously completely depended on high-priced imports (Tunsutapanich, 1980; Sahavchasin, 1981). Other countries in SEAsia and Central America (e.g. Vos \& de la Rosa 1980, Nacgel, 1979; Royan, 1981) are still in the nology to local conditions. So tor local conditions.

So far most efforia inoculation procho heduction outputs through inproved pond design and Artemiastrins beloging is well documened that

Hydrobiologia $108,17-23$ (1984).
ODr W. Junk Publishers, The Hague. Printed in the Netherlands. differ largely in many characteristics (see reviews by
Sorgeloos, 1980, in press) little or no attention has been paid to the impact of environmental effects on the quality of Artemia cysts produced by inoculated populations.

In this study we report about differences between inoculated Artemia cysts and cysts harvested after few months production in the inoculated salt pond in the Philippines (at Barotac Nuevo in 1978 and at Jaro in 1981), Thailand (at Bangpakong in 1979) and India (at Mundra in 1979).

The following characteristics were analyzed: hatching rate and efficiency: radiation sensitivity and nauplius survival (Meade, 1976);

cyst diameter which is proportional to the nauplius length (Vanhaecke \& Sorgeloos, 1980a and has its importance with regard to the ingestibility of the nauplii by early live stages of cul-

survival and growth of the nauplii as importan color of the cyst's shell which correlates with

\begin{tabular}{|c|c|c|c|c|c|c|c|}
\hline Site & $\begin{array}{l}\text { Pond } \\
\text { surface } \\
\left(\mathrm{m}^{2}\right)\end{array}$ & $\begin{array}{l}\text { Water } \\
\text { depth } \\
(\mathrm{cm})\end{array}$ & $\begin{array}{l}\text { Water } \\
\text { temmerature } \\
\left({ }^{\circ} \mathrm{C}\right)\end{array}$ & $\begin{array}{l}\text { Salinity } \\
\text { range. } \\
(\%(\%))\end{array}$ & Food & $\begin{array}{l}\text { Origin of cysts used } \\
\text { for inoculation }\end{array}$ & $\begin{array}{l}\text { Batch identification } \\
\text { of cyssts harvested } \\
\text { from inoculated } \\
\text { ponds }\end{array}$ \\
\hline $\begin{array}{l}\text { Bangpakong } \\
\text { (Thailand) }\end{array}$ & 220 & $20-30$ & $25.5-37.0$ & 100.150 & $\begin{array}{l}\text { Natural productivity } \\
\text { (regular mangrove } \\
\text { water intake) }\end{array}$ & $\begin{array}{l}\text { San Francisco Bay Brand } \\
\text { Cy batch } 1728 \text { (SFB 1728) }\end{array}$ & BP 1979 \\
\hline $\begin{array}{l}\text { Barotac Nuevo } \\
\text { (Philippines) }\end{array}$ & 16000 & 30 & $25.0-37.0$ & $80-170$ & $\begin{array}{l}\text { Natural productivity } \\
\text { (regular mangrove } \\
\text { water intake) }\end{array}$ & $\begin{array}{l}\text { San Francisco Bay Brand } \\
\text { Cy batch } 2596 \text { (SFB 2596) }\end{array}$ & BN 1978 \\
\hline $\begin{array}{l}\text { Jaro } \\
\text { (Philippines) }\end{array}$ & 1250 & $30-45$ & $25.0-37.0$ & $100-140$ & $\begin{array}{l}\text { Inorganic fertilisation } \\
\text { (regular brine intake) }\end{array}$ & $\begin{array}{l}\text { Barotac Nuevo batch } \\
1978 \text { (BN 1978) }\end{array}$ & JA 1981 \\
\hline $\begin{array}{l}\text { Mundra } \\
\text { (India) }\end{array}$ & 3000 & 40 & $28.0-35.0$ & $100-160$ & $\begin{array}{l}\text { Natural productivity } \\
\text { (regular mangrove } \\
\text { waler intake) }\end{array}$ & $\begin{array}{l}\text { San Francisco Bay Brand } \\
\text { Cy batch } 2596 \text { (SFB 2596) }\end{array}$ & MU 1979 \\
\hline
\end{tabular}

criteria in culturing;

biochemical composition and nutritional value of freshly-hatched nauplii for cultured species.

had grown to adult size and started to produce cysts (oviparous reproduction) and nauplii (ovoviviparous reproduction)

In a first phase the ovoviviparous reproduction mode was favored by maintaining the salinity levels close to $100 \%$; as a consequence, the continuous recruitment assured a fast increase of the population. After about 2-3 months the salinity levels were allowed to increase by evaporation and the overall mode of reproduction switched to oviparity.

Floating cysts aggregated in dense patches in the corners of the ponds from where they were regularly harvested with scoop nets. The cysts were the processed following the recommendations by Sorgeloos et al. (1978) and Sorgeloos (1978) to give clean and dry product which was eventually store under vacuum until further analysis. Productio yields, extrapolated from individual ponds, ranged from 10 to $60 \mathrm{~kg}$ dry cysts $/ \mathrm{ha} / 5$ month period. More details on the production conditions at the various inoculation sites can be found in Table and in the papers of De los Santos et al. (1980), Royan(1981), Tunsutapanit (1979) and Vos (1981).

\section{Cy'st hatching efficiency and hatching rate}

The hatching efficiency was determined a $25^{\circ} \mathrm{C}$ under continuous illumination of 1000 lux, and in $35 \%$ seawater according to Sorgeloos et al. (1978) and was expressed as the number of nauplii hatched minat and cyss. The harching rate was deter- 
procedure mentioned by Vanhaecke \& Sorgeloos (1982) and expressed as hours of incubation needed to reach 0,50 , and $90 \%\left(\mathrm{~T}_{0}, \mathrm{~T}_{50}, \mathrm{~T}_{90}\right)$ of the maximal hatching value.

\section{Cyst diameter}

The diameter of fully hydrated cysts was determined with Coulter Counter equipment according to the technique described by Vanhaecke $e t$ al (1980).

\section{Nauplius survival and grou'th}

Survival and growth of the nauplii hatched from the different cyst batches were determined in the standard culture test of Vanhaecke \& Sorgeloos (1980b) using San Francisco Bay batch no 2882596 Artemia as reference material. After 7 days culturing on a Dunaliella diet, the percent survival and the average length of the larvae were determined. The growth of the nauplii was expressed as a percentage of the growth recorded for the reference strain.

\section{Nutritional evaluation}

The nutritional evaluation studies were limited to a fatty acid analysis of the nauplii and to a culture test with the marine mysid Mysidopsis bahia. For the fatty acid analysis instar I nauplii were homotenizedina Uliratra homogenizer and extracted

Table 2. Characteristics of cysts and nauplii from parental cysts and from cysts harvested from inoculated populations (legend to

\begin{tabular}{|c|c|c|c|c|c|c|}
\hline & $\begin{array}{l}\text { SFB } \\
1728\end{array}$ & $\begin{array}{l}\text { BP } \\
1979\end{array}$ & $\begin{array}{l}\text { SFB } \\
2596\end{array}$ & $\begin{array}{l}\text { BN } \\
1978\end{array}$ & $\begin{array}{l}\text { JA } \\
1981\end{array}$ & $\begin{array}{l}\text { MU } \\
1979\end{array}$ \\
\hline $\begin{array}{l}\text { Hatching efficiency (nauplii/g) } \\
\text { Hatching rate characteristicss }\end{array}$ & 100800 & 304000 & 267200 & 214000 & 339200 & 236800 \\
\hline $\mathrm{T}_{0}$ & 24.5 & 14.5 & 15.0 & 14.7 & 14.4 & 14.6 \\
\hline $\mathrm{T}_{30}$ & 32.8 & 18.8 & 17.6 & 18.8 & 17.6 & 16.3 \\
\hline $\begin{array}{l}\mathrm{T}_{90} \\
\text { Color of cysts }\end{array}$ & 39.2 & 25.6 & 20.5 & 22.0 & 22.0 & 18.9 \\
\hline $\begin{array}{l}\text { Color of cysts } \\
\text { diameter of cysts }(\mu \mathrm{m})\end{array}$ & pale & $\begin{array}{l}\text { dark } \\
2322\end{array}$ & pale & dark & dark & pale \\
\hline $\begin{array}{l}\text { diameler of cysts }(\mu \mathrm{m}) \\
\text { standard deviation }\end{array}$ & $\begin{array}{r}225.8 \\
17.3\end{array}$ & $\begin{array}{r}232.2 \\
11.8\end{array}$ & 224.7 & 228.0 & 225.2 & 222.1 \\
\hline $\begin{array}{l}\text { standard deviation } \\
\text { Nauplius survival at day } 7(\%)\end{array}$ & 94.3 & 96.8 & ${ }_{0.4}^{12.4}$ & $\begin{array}{l}13.0 \\
86\end{array}$ & $\begin{array}{ll}11.7 \\
\mathrm{c}\end{array}$ & 10.8 \\
\hline Nauplius growth at day $7^{\mathrm{b}}$ & 100 & 106 & 100 & 97 &. & $\begin{array}{l}88 \\
105\end{array}$ \\
\hline
\end{tabular}

${ }^{2}$ Values refer to time-lapses (in hours) from incubation until appearance of the first nauplii $\left(\mathrm{T}_{0}\right)$ or the moment by which $50 \%\left(\mathrm{~T}_{50}\right)$ and $90 \%\left(T_{90}\right)$ of the hatching efficiency has been reached.

cNo data available. three times with a methanol: chloroform: water (2: 1:0.8) mixture (Bligh \& Dyer, 1959). The reing to the procedure of Schauer et al. (1980). Saponification and methylation were carried out as described by Schauer \& Simpson (1978). The separetion of the fatty acid methyl esters (FAME) was FTV 2300) gy gas chromatography (Carlo Erba AW $100-120$. The Altech CS-8 on chromosorb Wwere 120 . The gaschromatographic conditions Fi: $200^{\circ} \mathrm{C}$ isothermal; carrier gas $\mathrm{N}_{2} 40 \mathrm{ml} / \mathrm{min}$; F.1.D.-dection. The identification and quantificaFor are presented as area-percent compositions.

The standard culture test with Mysidopsis bahia larvae will be described in detail by Léger \& Sorgeloos (in prep.) Newborn mysid juveniles are transresh daily and after 12 days culturing, the growth and reproductive characteristics of the pre-adult mysids in a one way analysis of variance. The Duncan's $\checkmark \%$ transformation (Snedecor \& Cochran, 1967). 1728 were treated separately. maining solids were extracted with acetone accord(2) on a glass column $(1.8 \mathrm{~m} \times 2 \mathrm{~mm}$ I.D.) are analyzed. All the data were statistically analyzed icant differences anong means. Prior 10 analysis, Inoculation

Tahle 3. Results of Mrsidopsis feeding-test with Artemia nauplii from different cyst sources (legend to abbreviations in Table 1)

\begin{tabular}{|c|c|c|c|c|c|c|}
\hline \multirow[b]{2}{*}{ Mysis results } & \multicolumn{6}{|c|}{ Artemia source } \\
\hline & $\begin{array}{l}\text { SFB } \\
2596\end{array}$ & $\begin{array}{l}\text { MU } \\
1979\end{array}$ & $\begin{array}{l}\text { BN } \\
1978\end{array}$ & $\begin{array}{l}J A \\
1981\end{array}$ & $\begin{array}{l}\text { SFB } \\
1728\end{array}$ & $\begin{array}{l}\text { BP } \\
1979\end{array}$ \\
\hline$\underset{\mathrm{S}}{\text { Survival (\%) }}$ & $\begin{array}{l}93.3^{\mathrm{a}} \\
5.2\end{array}$ & $\begin{array}{l}86.7^{\mathrm{a}} \\
13.8\end{array}$ & $\begin{array}{c}94.0^{\mathrm{a}} \\
5.5\end{array}$ & $\begin{array}{l}75.0^{\mathrm{b*}} \\
10.6\end{array}$ & $\begin{array}{l}81.3 \\
11.0\end{array}$ & $\begin{array}{r}90.0 \\
8.9\end{array}$ \\
\hline Dry weight $(\mu \mathrm{g})$ & $\begin{array}{c}318.1^{\mathrm{a}} \\
44.1^{2}\end{array}$ & $\begin{array}{c}371.9^{\mathrm{a}} \\
47.7\end{array}$ & $385.8^{\mathrm{a}}$ & $264.0^{\text {b*** }}$ & $\begin{array}{r}306.6 \\
22.4\end{array}$ & 311.9 \\
\hline${ }_{\text {Length }}^{\mathrm{s}}(\mu \mathrm{m})$ & $\begin{array}{r}44.1 \\
4467^{7 * *}\end{array}$ & $\begin{array}{r}47.7 \\
4479^{\mathrm{a}}\end{array}$ & $\begin{array}{r}48.2 \\
4366^{\mathrm{h} *}\end{array}$ & $\begin{array}{r}31.8 \\
3192<*\end{array}$ & $\begin{array}{r}22.4 \\
4748\end{array}$ & $\begin{array}{r}37.1 \\
4758\end{array}$ \\
\hline & 185 & 181 & 170 & 193 & 166 & 145 \\
\hline \multicolumn{7}{|c|}{ Reproductive data $(\%)$} \\
\hline 0.80 & $\begin{array}{r}4.6 \\
506\end{array}$ & $\begin{array}{c}0 \\
133\end{array}$ & $\begin{array}{l}0 \\
80\end{array}$ & $\begin{array}{c}0 \\
48.2\end{array}$ & $\begin{array}{c}0 \\
48.8\end{array}$ & $\begin{array}{c}0 \\
303\end{array}$ \\
\hline $\begin{array}{l}9.199 \\
9_{i} / 199 \\
0^{1}\end{array}$ & $\begin{array}{l}50.6 \\
49.4\end{array}$ & 73.5 & 76.0 & 51.9 & 51.2 & 51.5 \\
\hline $\begin{array}{l}7 m / Q q \\
9^{m} / Q q\end{array}$ & 0 & 13.3 & 16.0 & 0 & 0 & 18.2 \\
\hline
\end{tabular}

Legend to stmbols

. Means with a different superseript (a,b,c) are significantly different at the $*: 0: 05$ or $* \alpha: 0.01$ level.

Oi immature male

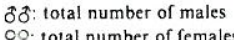

९o: female with eggs in ovaria

\section{Results}

The characteristics of cysts and nauplii from the various cyst products are summarized in Table 2 . Apparently the hatching efficiencies, hatching rates and cyst colors were altered after inoculation. On the other hand the cyst's diameter, nauplius survival and nauplius growt h showed only minor changes as a result of the new environmental conditions. The most pronounced differences were noted for the hatching quality criteria. The results showed that upon inoculation not only poorer (e.g. Barotac Nuevo) but also better qualities (e.g. Bangpakon \& Jaro) may be harvested. The cyst's color changed from pale to dark in some inoculated products (Bangpakong \& Barotac Nuevo) but remained dark in the Jaro and pale in the Mundra-inoculations. Production performances of the mysid larvae fed with the various Arremia products are summarize in Table 3. High survival rates were observed for al the nauplii products. After 12 days of culturing, all mysids reached sexual differentiation. The survival, growth and reproductive characteristics obtaine with a diet of Artemia from Mundra, Barotac Nu evo \& Bangpakong were at least as good as the dat recorded for mysids fed with parental Artemia material (SFB 2596 and SFB 1728 respectively). growth were noticed between test-animals fed Jaro and those fed the parental Artemia from Barotac Nuevo.

From Table 4 it is clear that the fatty acid profile varied considerably among Artemia nauplii from the different sources. In view of the importance of the highly unsaturated fatty acids for marine animals (Schauer et al., 1980: Watanabe et al., 1980; Léger et al, in prep.) the deficiency for the essential fatty acid (E.F.A.) 20:5 33 in Artemia nauplii from Jaro is obvious.

\section{Discussion}

It is very likely that the variations observed in the quality of cyst hatching between the parental cysts and those harvested from the inoculated populations are due to differences in cyst harvesting-, processing- and storage techniques.

From the studies of Sorgeloos et al. $(1976,1978)$ and Vanhaecke \& Sorgeloos $(1982,1983)$ it appears indeed that essential variables in this respect are the regularity of harvesting; the percentage composition of the product in full cysts, empty cysts and debris; the water content of dry cysts, the method used for drying and storage, etc. Up to now, no 
Tathle t. Procentual composition of fatty acid methyl esters (F.A M.E.) of Artemia nauplii from the different cyst sources

\begin{tabular}{|c|c|c|c|c|c|c|}
\hline F.A.M.E. & $\begin{array}{l}\text { SFB } \\
2596\end{array}$ & $\begin{array}{l}\text { MU } \\
1979\end{array}$ & $\begin{array}{l}\text { BN } \\
1978\end{array}$ & $\begin{array}{l}\text { JA } \\
1981\end{array}$ & $\begin{array}{l}\text { SFB } \\
1728\end{array}$ & $\begin{array}{l}\mathrm{BP} \\
1979\end{array}$ \\
\hline $14: 0$ & 1.3 & 0.9 & 1.7 & 1.4 & 1.8 & 0.7 \\
\hline $14: 1$ & 0.9 & 2.4 & 1.4 & 1.5 & 0.9 & 2.6 \\
\hline 15:0 & 0.3 & 0.9 & 1.4 & 1.5 & 1.3 & \\
\hline $15: 1$ & 0.2 & 1.4 & 0.7 & 0.8 & 0.7 & 0.7 \\
\hline $16: 0$ & 13.0 & 12.7 & 14.4 & 11.4 & 14.4 & 10.1 \\
\hline $16: 1 \omega 7$ & 21.9 & 8.9 & 15.9 & 13.7 & 16.3 & 10.3 \\
\hline $16: 2 \omega 7 \quad 17: 0$ & & 1.6 & 1.9 & 2.1 & 1.3 & \\
\hline $16: 3 \omega 4 \cdot 17: 1 \omega 8$ & 0.8 & 2.3 & 4.0 & 4.7 & 5.3 & 1.3 \\
\hline $18=0$ & 3.0 & $\begin{array}{r}2.8 \\
.79\end{array}$ & 23.3 & 3.9 & 3.3 & 2.9 \\
\hline $18: 1 \omega 7 \quad \omega 9$ & 34.1 & 27.9 & 29.6 & 27.0 & 28.0 & 31.4 \\
\hline 18: $2 \omega 6$ & 4.7 & 12.0 & 9.1 & 15.0 & 4.5 & 5.5 \\
\hline$\left.\begin{array}{l}20: 0 \\
18.3 \omega^{3} \omega 6\end{array}\right|^{4}$ & 7.8 & 14.6 & 4.2 & 12.9 & 9.2 & 23.3 \\
\hline $18: 4 \omega 3$ & 1.9 & 3.0 & 1.2 & 1.1 & 1.1 & \\
\hline $20: 2 \omega 6 \omega 9$ & 0.2 & 0.3 & 0.3 & 0.5 & 0.4 & 0.3 \\
\hline $20: 3 \omega .3$ w & 0.1 & 0.2 & 0.2 & & 0.2 & 0.1 \\
\hline $20: 4,43, w 6$ & $\begin{array}{l}1.9 \\
0.3\end{array}$ & 1.5 & 2.1 & 1.3 & 2.5 & 1.7 \\
\hline $22: 1$ & 0.3 & 0.8 & 0.3 & 0.1 & 0.2 & 0.6 \\
\hline $\begin{array}{l}20: 5 \omega 3 \\
22: 2=21: 5\end{array}$ & 7.9 & 5.3 & 8.6 & 1.9 & 13.8 & 5.3 \\
\hline $\begin{array}{l}22: 2: 21: 5 \\
24: 0\end{array}$ & & $\begin{array}{l}0.3 \\
0.2\end{array}$ & & & & \\
\hline $22: 6$ & & 0.1 & 0.3 & & & \\
\hline
\end{tabular}

"More than 99"; 18: $3 \omega^{3}$.

onment on the cyst hatching quality is available The results prove, however, that even an inoculation with low quality cysts can produce excellen cysts. The hatching quality of the parental materi should therefore not be considered as an importan strain selection-criterion for inoculation.

In the Philippine and Thai inoculations, the harvested cysts always had a dark brown color which indicas a high hema 1060$)$ whe in the cyst's shell (Gilchisi a Green, 1960) which in turn is probably correlated witha high heglobinconplays an obvious role through the Fe-content of the inested food and low oxyzen concentrations of the water. Thus the marked difference between San Francisco Bay parent cysts and Baroc Nuevo Francisco Bay parente and Thai cysts on one hand, and the persistence of the daro in callo plained by the much higher average water temperaplained by the much higher average wa cer temperain these tropical conditions as compared to the San Francisco Bay environment. The effect of the salinity concentrations can be neglected in this comparison since the San Francisco Bay cysts are produced in similar salinity ranges (Carpelan. 1957: Baker 1966; pers. observ.). The same reasoning applies to produced since 1978 from another San Francisco Bay transplantation (Sorgeloos al., 1979). Ih is. however, not a general rule that in hor tropica Mundra cysts which were exposed to equally he and saline conditions as the Thai and Philippine

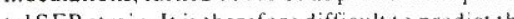
cyst's corain. Ih is the whole set of environ is sect factors, but itceetainly is not a strain-dependent characteristic. The constancy of the cyst's diameters corerall (97-106\% of growith strain) confirms the earlier conclusion of $Y$ anhaecke \& Sorgeloos (1980a, b) that hese characteristics are strain dependent and except for smidt differences, are unatered by a new environment. These characteristics are therefore essential criteri to be considered in selecting suitable strains for inoculation and transplantation purposes.

The poorer nutritional value of nauplii from. Jaro the dark colored Macau (Brazil) cysts which are biotopes darker cysts are produced. because the

The constancy of the cyst's diameters forerall
Artemia cysts for Misidopsis hahia correlates with lower content of the E.F.A. $20: 503$. This confirms the finding of Johns et al. (1981) and Léger $e t a l$ al. (in prep.) that Artemia nauplii with low levels of 20:5 53 give poor production results when offered as food to Mysidopsis juveniles. The lower content of particular fatty acids in the nauplii is probably explained by similar profile differences of the food ingested by the cyst-producing adults (Hinchcliffe \& Riley, 1972). Food management of the ponds is therefore of crucial importance. Up to now, however, no specific management guidelines exist in this respect becausetracal conditions vary considerably. The Jaro inoculation was the only one where the fertility of the water (brine from the adjacent saltfarm) was supplemented with inorganic fertiliza tion. This resulted in blooms of reddish-colored algae which might not have been an ideal food for Artemia. It therefore seems that the safest results may be obtained in those inoculations where the available food has a great composition diversity. such as in inoculations using the natural fertility of intake water (e.g. mangroves, estuaria) and or organic fertilizers as is presently routinely done in Thailand with excellent results.

In view of the importance of sufficient levels of 20:5 3 in Artemia nauplii, and considering the fact that fatty acid proflies are mainly determined by the composition of the assimilated food, one cannot assure that inoculation with good quality cysts will result in cysts of an equally high nutritional value.

\section{Acknowledgements}

We are very indebted to Mr. Atty de los Santos, Mr. Erwin Pador and Mr. Mahesh Shania for providing us with cyst samples from Barotac Nuevo, Jaro and Mundra respectively. We furthermore like to thank ir. Eddy' Naessens-Foucquaer for his assistance in the nutritional work and Dr. ir. E. Jaspers for proofreading the manuscript. The material from Bangpakong was produced by one of us (J.V.) under contract THA:75:008 with the Food and Agriculture Organisation of the United Nations. Ph. L. is a 'Research Assistant' and P.S. Scientific Research (N.F.W.O.- Belgium).

\section{References}

Baker. M. J., 1966. Autecology of Artemia: Factors influencin Sun Erancisco State College, 117 p extraction and purilication. Can. J. Biochem. Physiol. 37. 911917

Carpelan, L. H.. 1975. Hydrobiology of the Alviso salt pund.

Peos P. Laviñ E A.. 1980 . Successful inoculation of Artemia and produclion of cysts in man-made salterns in the Philippines. In: Persoone. G.. Sorgeloos. P., Roels, O. \& Jaspers. E. (ed, .) The

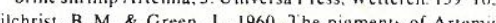
Proc. r. Soc., B. 152: 118-136. inchcliffe. P. R. \& Riley, J. P.. 1972. The effect of diet on the component fatty-acid composition of Artemia salina. J. ma

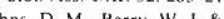

\& Waltion, W, 1981. Internationa Study on Artemia. 16. Survisal, growth and reproductiv potential of the mysid. Mysidopsis bahia Molenock fed var-
ious geographical collections of the brine shrimp. Artemia. exp. mar. Biol. Ecol. 53: 209219

eer. Ph. \& Surgeloos. P... in prep. Description of a standar (Crustacea, Mysidacea) for the evaluation of the nutritional value of live Artemia nauplin.

Leger, Ph., Vanhaecke, P.. Simpson, K. L. \& Sorgeloos. P... in of Artemia nauplii from on Artemia. 25. Nutritional salue

Meade. J. W.. 1976. Advances in the intensive rearing of the brine shrimp (Arlemia salina). M. Sc. Thesis. Penn St. Lnis. University Park. $64 \mathrm{pp}$.

cerel. L. C. A., T979. Status. potentials and problems of mari Ann. Meet. Wurld Maricult Soc Luisiana State Unitersits Press. Baton Rouge: 570576.

Persoone, G. \& Sorgeloos. P., 1980. General aspects of the ecology and biogeography of Artemia. In: Persoone. Gi

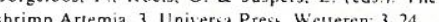

Roy an. J. P.. 1981. Brine shrimp culture. In: Status Report on Coastal Ayuaculture in India. Nat. Inst. Oceanogr.. Goa

hásin. S., 1981. Ways to cunvert salt farm to Artemia her. Thai Fish. Gaz. 34.467 .480

1980. International S. M., Olney, C. E. \& Simpson, K. L. content and fatts acid composition of the cysts and new! In: Persoone. G. Sorgeloos, P. R Rels. O. \& Jasterna (eds.). The brine shrimp Artemia. 3. Unuersa Press. Wetteren: 365.37 .

Schauer. P. S. \& Simpson. K. L.. 1978. Effects of diets on the fatty acid composition of juvenile autlantic silitersides (Meni- 
World Maricult. Soc. Louisiana State University Press, Baton Rouge: 175-187. The lowa State Lini ersity Press. Ames. 593 pp
The

Sorgeloos. P... Yy and fish in South East Asia. FAO Report TAH 75; 00878 WP3. 50 pp.

Sorgeloos, P.. 1980. The use of the brine shrimp Artemia ayuaculture. In: Pels soone, G.. Sorgeloos, P.. Rocls. O. Pess. Weveren: 25.46.

Live animal food for larval rearing in aquaculture: the brine shrimp Artemia. In: Bilio, M., Ros-

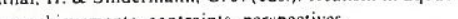

Sorgeloos. P. Baeza-Mesa. M... Benijts. F. \& Persoone. G. 1976. Current research on the culturing of the brine shrimp In. Persoone, G. \& Jaspers. E. (eds.). Proc. 10th European Symp. mar. Biol.. 1. Universa Press, Wetteren: 473.495. Sorgeloos. P... Bossuyt. E., Bruggeman, E... Cooreman. A., Dob-
beleir. J.. Vanhaecke, P. \& Versichele. D., 1979. Progress report on the research activisies of the Artemia Reference Center. ICES C.M. F 54: 206-214.

Sorgelous, P., Persoone. G., Bacza-Mesa. M.. Bossuyt. E. Bruggeman. E.. 1978. The use of Artemia cysts in aquacu-

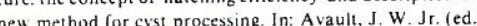
Proc. 9th Ann. Meel. World Maricult. Soc. Louisiana State Uniersity Press, Baton Ruuge: 715-721.

Unsutapanit. A., 1980. Cyst production of Artemia in Thai salt ponds. In. A. S Provional Repur Artemia. 4. The biometrics of Artemia strains from different O. \& Jaspers. E. (ed.). The brine shrimp Artemia. 3. Linuersa Press. Wetteren: 39340 .

A A Sorgeloos. P. 1980b. International Siudy on A

Ecol. Prog. Ser. 3: 3030307.
Vanhaecke. P. \& Sorgeloos, P.. 1982. International Study on

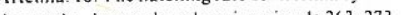
A

tudy on brine shrimp cysts and re-evaluation of the 'hatching effidency' concept. Ayuaculture. 30: 43 52.

. for the biometrical analysis of Artemia cysts. Methodolog and mathematics. In: Persoone. G., Sorgeloos. P. Roels. O. \& Jaspers, E. (eds.). The brine shrimp Arlemia, I. L'nivers Press. Wetteren. I07- ils.

Proction in salt punds in the

(2. De La Rosa, N. L.. 1980. Manual on Arlemia producManual on Arlemla produc-
Wines. FAO UNDP-BFAR Project Manual. PHI 75 . 005 W'PG, 48 pp.

report on Artemis FAO UNDP Field Document, THA 75 008.54 50

Watanabe, T., Oowa, F., Kitajima. C.\& Fujita. S., 1980. Nurritional studies in the seed production of frish. 9 . Relationsh. their content of $\omega 3$ highly unsaturated fauls acids. Bull Jap. Soc. scient. Fish. 46: 35-41.

Received 24 August 1982; accepted 20 October 1982 